\title{
Combination of Cyclic Steam Stimulation and Steam Flooding to Improve Oil Recovery in Unconsolidated Sand Heavy Oil Reservoir
}

A M Suranto ${ }^{1 *}$, Boni Swadesi ${ }^{1}$, Indah Widyaningsih ${ }^{1}$, Ratna Widyaningsih ${ }^{1}$, Sri Wahyu Murni ${ }^{2}$, Lufis Alfian Alannafi ${ }^{1}$

${ }^{1}$ Department of Petroleum Engineering, Universitas Pembangunan Nasional Veteran Yogyakarta, Jl. Ring Road Utara, Condong Catur, Yogyakarta, Indonesia - 55283

${ }^{2}$ Department of Chemical Engineering, Universitas Pembangunan Nasional Veteran Yogyakarta, Jl. Ring Road Utara, Condong Catur, Yogyakarta, Indonesia - 55283

*Corresponding Author: su_ranto@upnyk.ac.id

\begin{tabular}{|c|c|}
\hline Article History: & Abstract \\
\hline $\begin{array}{l}\text { Received: February 17, } 2020 \\
\text { Receive in Revised Form: May 30, } 2020 \\
\text { Accepted: June 2, } 2020\end{array}$ & \multirow{3}{*}{$\begin{array}{l}\text { The steam injection can be a success in increasing oil recovery by } \\
\text { going up the steam chamber volume. It will impact on the stean } \\
\text { distribution and steam performance in covering hot areas in th } \\
\text { reservoir. An injection plan and a proper cyclic steam stimulation } \\
\text { (CSS) schedule are critical in predicting how the steam chamber car } \\
\text { grow and cover the heated area. A reservoir simulation model wil } \\
\text { be used to understand how the CSS impacts in steam chambe } \\
\text { generation and affects the oil recovery. This paper generatec } \\
\text { numerous scenarios to see how steam works in heavy oil systems } \\
\text { particularly in unconsolidated sand reservoirs. A combination of th } \\
\text { CSS and steam flooding methods was investigated in this research } \\
\text { Further, we validated the scenarios based on how fast the stean } \\
\text { chamber could grow and produce maximum oil recovery. Th } \\
\text { reservoir simulation showed how steam chamber behavior in } \\
\text { unconsolidated sand improved oil recovery. Finally, it is reveale } \\
\text { that combining the CSS and the steam flooding caused a faster stean } \\
\text { chamber growth and higher oil recovery by } 61.5 \% \text { of the heavy oi } \\
\text { system. }\end{array}$} \\
\hline Keywords: & \\
\hline $\begin{array}{l}\text { Heavy Oil, Steam Chamber, CSS, Steam } \\
\text { Injection, Simulation. }\end{array}$ & \\
\hline
\end{tabular}

\section{INTRODUCTION}

The remaining reserve of light oil in the world declines, and heavy oil resources will play an increasingly important role in developing the world economy (Hou et al., 2016). Nowadays, field development, which uses a primary and secondary method, is not more efficient due to its high viscosity of heavy oil. Therefore, the steam injection can be a solution to produce heavy oil. In the steam injection process, the injected steam causes increasing reservoir temperature and decreasing oil viscosity. The mobility of heavy oil is getting higher, leading to a lift up the oil more quickly to the surface (Butler, 1991; Hong, 1994). The success in improving oil recovery using steam injection is determined by steam chamber growth as a steam distribution in a specific reservoir area. Therefore, an efficient steam injection plan is needed to gain maximum production both in engineering and economic sides (Nasr \& Ayodele, 2005).

In comparison, the steam injection's failure can also happen due to ineffective steam performance in reaching the heated zone in the reservoir. The ineffective steam performance can disturb the reservoir's maturity because the steam will direct to the production well. Consequently, the heating steam is not suitable for the target (Hong \& Stevens, 1990). The heavy oil which has not been steamed has low mobility so that high residual oil saturation will occur in that zone.

Steam stimulation is generally applied periodically. This process can be called a steam soak process, cyclic steam stimulation, and Huff and Puff process. Naturally, the steam stimulation's purpose as the same as a thermal injection is to improve the productivity of the well by decreasing oil viscosity (Azad et al., 2013). If the oil viscosity decreases, the mobility of oil will increase and tend to move to the well with ease. The cyclic steam stimulation differs from the steam flooding. In the thermal injection process using the steam 
drive, the whole reservoir rocks will be heated continuously. This process helps to force oil to produce through production well. In the cyclic steam stimulation, steam is injected through the production well and has to be done within several days or weeks. After going through those processes, the well is soaked for several days. When the soaking period occurs, the oil viscosity and its mobility change due to the injected heat. After the soaking period, the production well can be produced. Sequential steps of the cyclic steam stimulation are applied periodically when the oil is still available in the surrounding of well production (Ali, 1994; Sheng, 2013).

Steam flooding is a process to enforce oil. The principle of steam flooding is the same as water injection. Steam injected through the injection well will boost the oil to be produced through the adjacent production well. During the steam flooding, several created zones will have their particular characteristics. Those zones are divided based on temperature and fluid saturation, i.e., steam zone, solvent zone, hot water zone, condensate zone or oil bank, and reservoir fluids zone. Each zone has an enforcement mechanism to the oil that causes fluids saturation to distribute evenly. The temperature profile between injection and production well will be decreased gradually (Hong, 1994).

A combination of the cyclic steam stimulation and the steam flooding is one of the alternatives to minimize both methods' flaws. In the first mechanism, the CSS recovers the oil from the surrounding of the well. After that process, the steam flooding pushes the oil, which is in the different areas, from the injection toward the production well. The process will continue until the steam recovers the oil, which lies between the injection and production well. If the residual oil saturation between the injection well and the production well is low, the condition will be unfavorable. Therefore, steam flooding should be stopped.

\section{MATERIALS AND METHODOLOGY \\ Maximizing the combination of cyclic steam stimulation and steamflooding}

The proses of this research are displayed in Figure 1. The first step is to build a basic reservoir model. Hereafter, the CSS is employed in this model. In this case, sensitivity analyses of operating condition are controlled to find a good condition which has a high cumulative production and a low cumulative steam oil ratio (cSOR). The steam injection rate is selected to be suitable for the temperature target. On the other hand, steam flooding is installed in the model. The operating conditions are similar to the CSS scenario, which are steam quality, steam injection rate, and bottom hole pressure. To get the optimum process, the CSS well uses Smart Completion, where its perforation interval modified into two parts consists of the upper part (injection) and the lower part (production) (Suranto et al., 2014, 2016). In the upper part, the perforation interval is $40 \mathrm{ft}$, while in the lower part is $60 \mathrm{ft}$. Packer is applied between those perforation intervals. For tubing, Interval Control Valve (ICV) is applied to connect two perforation zones. During the injection process, the upper part perforation is opened, while the lower part is closed. Otherwise, during the production process, the upper part perforation is closed, while the lower part is opened.

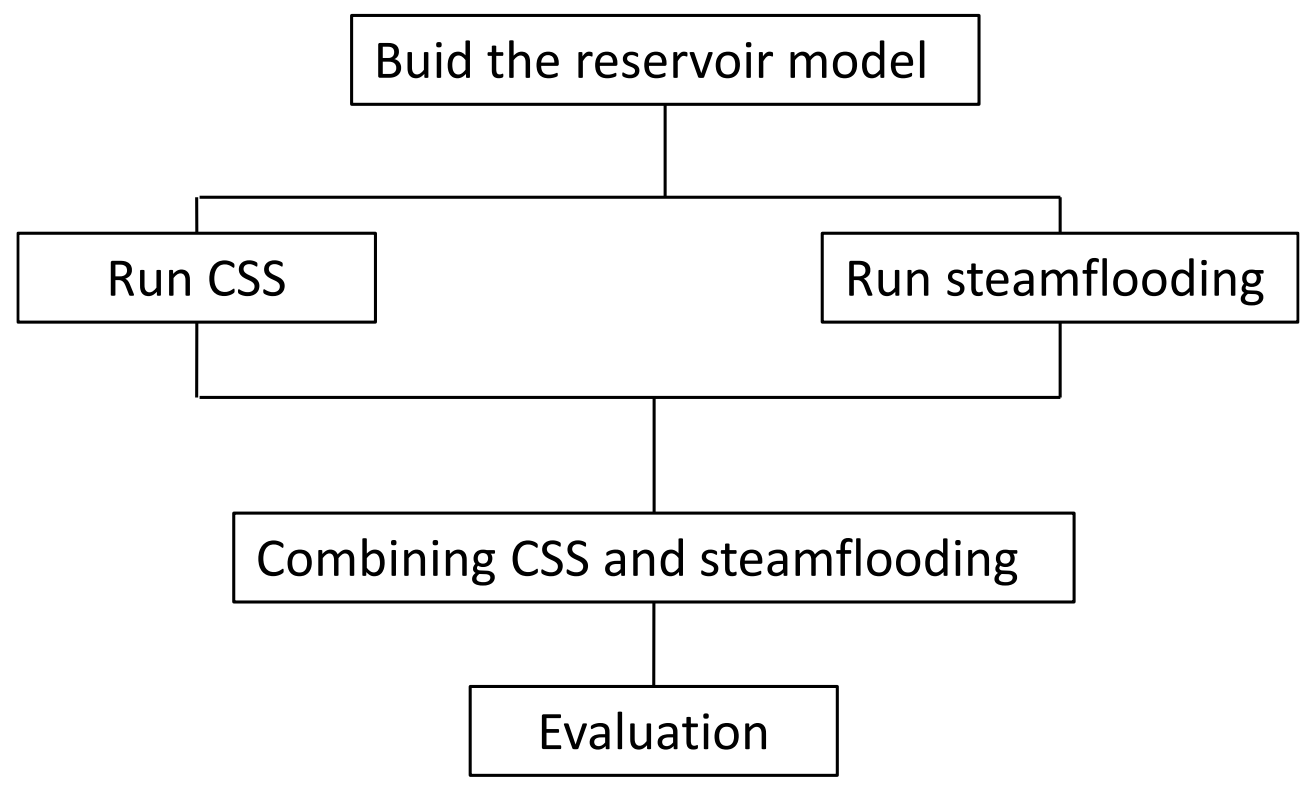

Figure 1. Flowchart of the process

The last investigation is to install the combination of the cyclic steam stimulation and steam flooding. In this process, the cyclic steam stimulation runs for three years. After that, steam flooding is employed in 
the model. It is noticed that there are three scenarios that should be running in the model, and finally, the result should be evaluated.

\section{Description of Reservoir Model}

The thermal reservoir simulator, STARS Version 2015 by Computer Modeling Group, constructs the reservoir model. A reservoir model represents generic Pertama and Kedua Formations in Duri Field, Indonesia. It consists of one vertical well in the center and six well surrounding from the center. It can be called seven spots inverted. Because data is limited (Gael et al., 1995), the rock and fluid properties are assumed to be homogeneous in the whole reservoir. The oil column thickness is fixed for all layers. The ratio of the horizontal permeability to the vertical permeability is 0.5 . The number of the grid is $33 \times 17$ $\times 6(\mathrm{i}, \mathrm{j}, \mathrm{k})$. The injection steam quality is equal to 0.8 , and the steam temperature is $432^{\circ} \mathrm{F}$. The CSS and steam flooding processes were simulated using this reservoir model. The reservoir simulation can help analyze how steam works in the heavy oil system, particularly in the unconsolidated sand reservoir. Table 1 displays the reservoir model characteristic, and Figure 2 shows the 3D model of visualization of the reservoir model.

Table 1. Reservoir model properties

\begin{tabular}{|c|c|}
\hline Reservoir properties & Value \\
\hline Grid type & Cartesian \\
\hline Grid system & Quick Pattern Grid \\
\hline Grid configuration (i $\mathrm{x} \mathrm{j} \mathrm{x} \mathrm{k)}$ & $33 \times 17 \times 6$ \\
\hline Total Grid & 3366 \\
\hline Grid size $(\mathrm{ft})$ & $19 \times 33$ \\
\hline Depth of Top Grid (ft) & 500 \\
\hline Reservoir Pressure (psi) & 100 \\
\hline Reservoir Temperature $\left({ }^{\circ} \mathrm{F}\right)$ & 100 \\
\hline Net Pay Thickness (ft) & 120 \\
\hline Porosity & 0.34 \\
\hline $\mathrm{S}_{\mathrm{oi}}$ & 0.53 \\
\hline Permeability (md) & 1500 \\
\hline $\mathrm{k}_{\mathrm{v}} / \mathrm{k}_{\mathrm{h}}$ & 0.5 \\
\hline Rock compresibility (1/psi) & $5.7 \times 10^{-7}$ \\
\hline Oil Gravity $\left({ }^{\circ} \mathrm{API}\right)$ & 20 \\
\hline $\mathrm{B}_{\circ}(\mathrm{bbl} / \mathrm{STB})$ & $1 / 02$ \\
\hline Gas oil ratio (SCF/STB) & 15 \\
\hline Oil Viskosity @ $100^{\circ} \mathrm{F}(\mathrm{cp})$ & 330 \\
\hline Oil Viskosity @ 300F (cp) & 8.2 \\
\hline$S_{\text {wirr }}$ & 0.4 \\
\hline Sor to water & 0.25 \\
\hline$S_{\text {or }}$ to steam & 0.10 \\
\hline Rock heat capasity $\left(\mathrm{BTU} / \mathrm{ft}^{3}{ }^{\circ}{ }^{\circ} \mathrm{F}\right)$ & 33.2 \\
\hline Rock heat conduktivy (BTU/ft.day. $\left.{ }^{\circ} \mathrm{F}\right)$ & 27.4 \\
\hline Steam quality (fraction) & 0.7 \\
\hline Steam temperature $\left({ }^{\circ} \mathrm{F}\right)$ & 432 \\
\hline
\end{tabular}

To study the effect of improving oil recovery with the combination of steam flooding and CSS requires a simulator program. This research simulator generates a reservoir model with one pattern inverted 7-spot and an approximate area of 5.5 acres. Inverted 7-spot pattern is chosen among other patterns due to its effectiveness on generating more oil recovery (Kusumastuti et al., 2019). The reservoir model used the Cartesian grid type with a quick pattern grid system. In this area, well spacing is about $303.668 \mathrm{ft}$. This simulation ran for ten years. 


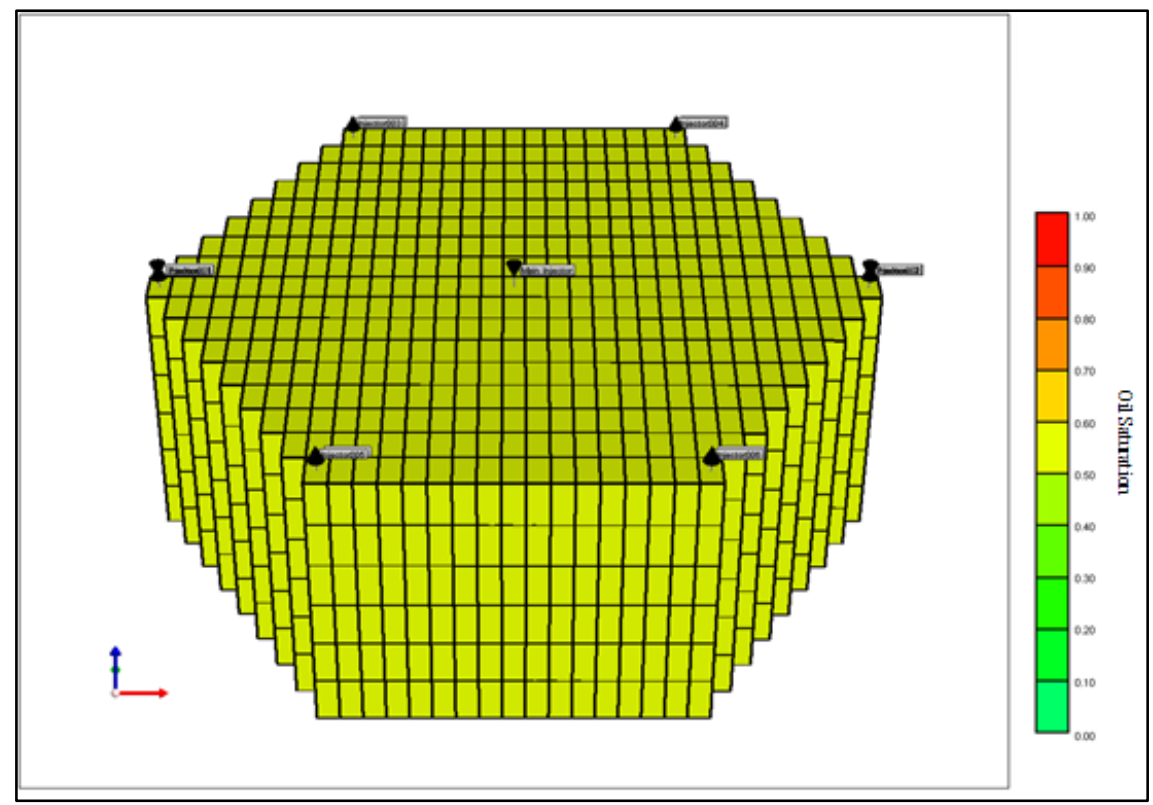

Figure 2. Schematic 3D view of the model

\section{RESULT AND DISCUSSION}

In order to get a maximum oil recovery, three scenarios have been employed. These are scenario 1 (CSS), scenario 2 (Steamflooding), and scenario 3 (CSS and Steamflooding) with the injection time of 30 days. Then, analyzing injection rate sensitivity is performed on the chosen scenario. Constraint used within the injection site well is the maximum injection rate of $450 \mathrm{BWPD}$ equivalent and Bottom Hole Pressure (BHP) of 350 psi. Simultaneously, the constraint used in production well is a minimum BHP of 70 psi that makes sense to use a pump. All constraints are ruled to all scenarios.

\section{A. Cyclic Steam Stimulation}

In scenario 1, the CSS applied in production well. The CSS for every well is done by injecting steam for 30 days, soaking period for five days, and the production time of 120 days. Figure 3 shows that extreme production rate change occurs following its CSS period. During the injection period, oil cannot produce because the tubing is used to flow the steam. Continually, the soaking period is applied to lower oil viscosity to increase oil mobility.

Consequently, the oil will be easily lifted to the surface at the early production period, so that the production rate increases significantly. A high production rate occurs quickly because the injected steam only heats oil around the perforation zone. After that, the production rate will decline drastically. The injection period in another cyclic should be applied before the heat in the production zone is lost. Therefore, the heat range can be added. After applying the CSS for third years, the production rate slightly decreased because the oil content in the surrounding of the well had been declined. Furthermore, the CSS target is oil, which is far from the wellbore instead of the close one. This scenario's result is the recovery factor, and the cumulative steam oil ratio (CSOR) obtained $40 \%$ and 2.5 , respectively. 


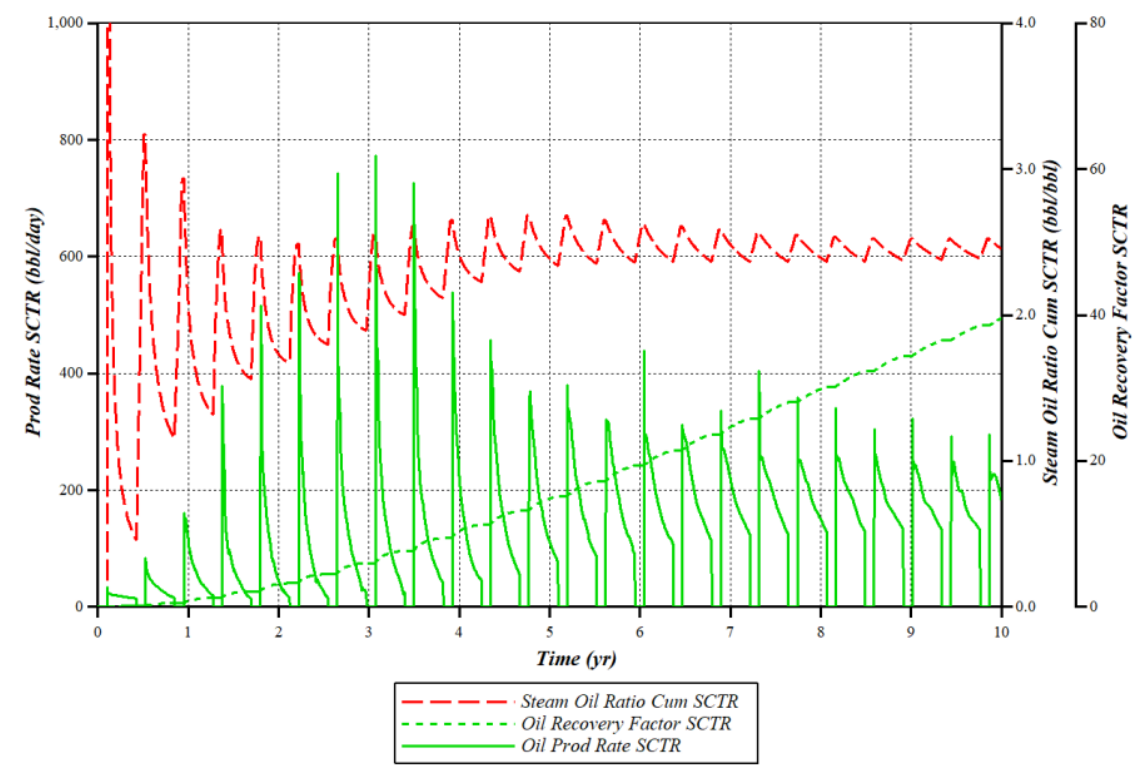

Figure 3. Production rate in CSS

\section{B. Steamflooding}

Scenario 2 uses the reservoir model with an inverted-7-spot-pattern, then the steam flooding is applied. In this process, initial production is relatively low, although the steam flooding is applied. Figure 4 displays the steam flooding period's production rate, where the steam breakthrough has not occurred at the initial injection time. The mechanism that dominantly drives oil before a breakthrough is a pressure from the injection well. It can be interpreted that the produced oil is the result of steam injection.

When the oil at the production zone has not been heated, the oil viscosity does not decrease and occurs a difficulty for oil to move. A steam breakthrough occurs in the middle of the $7^{\text {th }}$ year of simulation, as shown by the increase in production rate and the decrease of CSOR. As a breakthrough happens, steam has reached the production well that the heat will spread evenly throughout the reservoir. This condition can be called that the reservoir classified into the mature category. If the oil has been heated thoroughly, it will be easier to produce with a little cumulative steam. In this result, the CSOR in Scenario 2 is fewer than Scenario 1 because steam is injected only in one injection well in the middle. While in the CSS, the steam is injected from six production wells at the same rate. In Scenario 2, the obtained CSOR and recovery factors are approximately 1.8 and 34\%, respectively, indicating that those results are lower than those of scenario 1 .

Figure 5 shows the distribution of temperature in the four years after reservoir simulation work, as can be seen, that the heat distribution is growing up in the surrounding of the injection well. Despite the perforation has been installed in the lower part of the reservoir thickness, the steam chamber expands to the top side. It can happen because the density steam extremes lower than the reservoir fluid. Generally, steam flooding works continuously, so the production well side will be breakthrough quickly. On the other hand, the low part of between injection and production well will not be heated. Consequently, the recovery factor will be unsatisfied.

\section{Combining the cyclic steam stimulation and steam flooding}

In scenario 3, the reservoir model applied is a combination of the CSS in the production wells and the steam flooding in the injection well. The location of the injection well is the center of the model. In the initial year, the CSS simulation on the production well was done by using Smart Completion. Until then, in the 4.5 years, the CSS simulation keeps on running. In this case, the reservoir pressure rapidly decreased, and after that, in the second year, the steam flooding was initiated for running. If the pressure declines in the injector well area, steam can flow and grow up in the well's surroundings. As shown in Figure 6, in the $2^{\text {nd }}$ year, there is an increase of CSOR due to the addition of steam volume at the beginning of steam flooding. 


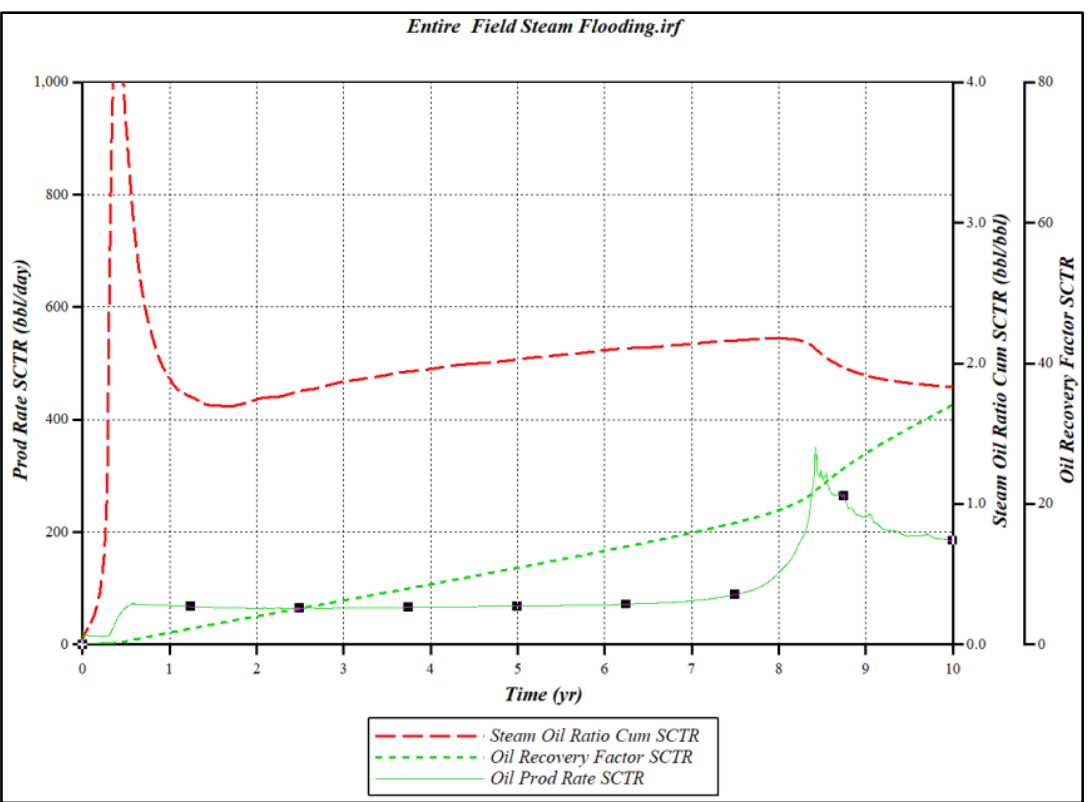

Figure 4. Production rate in the steam flooding

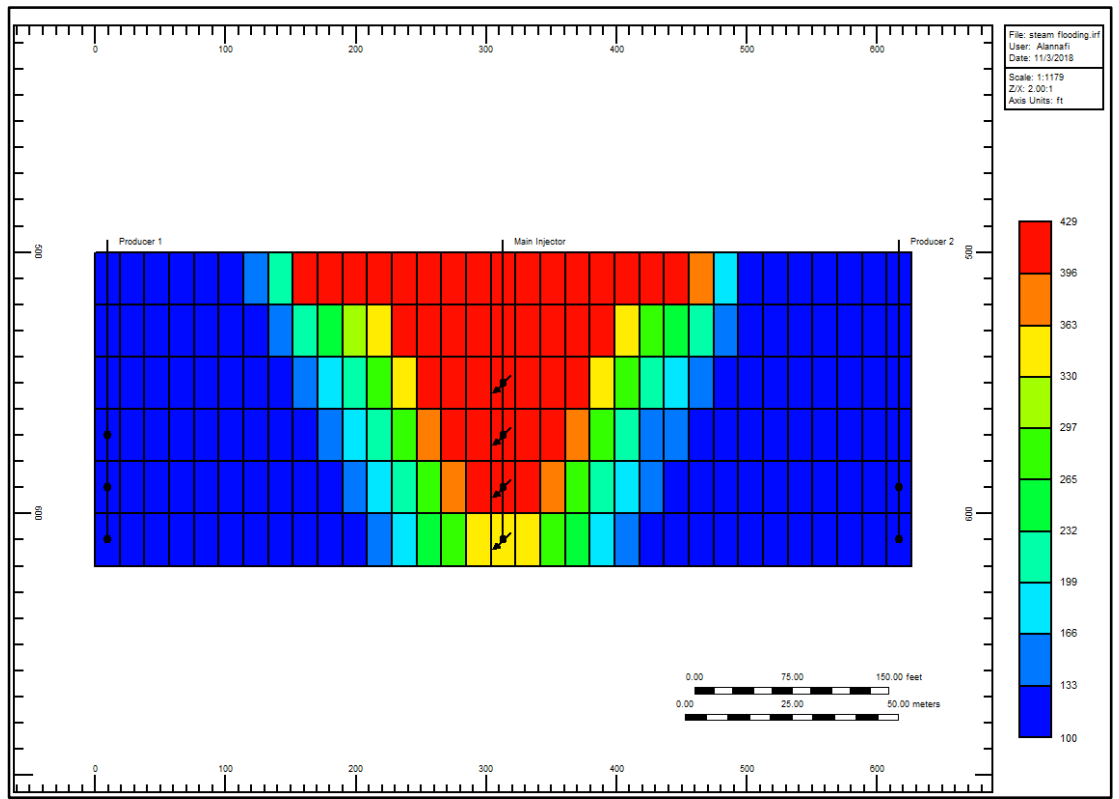

Figure 5. Temperature distribution of scenario 2 at the $4^{\text {th }}$ year simulation

The results of Scenario 3 obtained are a recovery factor of $63 \%$ and CSOR of 2.1. The CSOR of the scenario is lower compared to other scenarios because the combination will add the value of the injected steam. On the other hand, decreasing of CSOR will boost oil recovery significantly. In the $4^{\text {th }}$ year of the reservoir simulation, a breakthrough occurs because the steam injected from the injection zone, and the production zone will be connected. Scenario 3 obtains a faster breakthrough than other scenarios. 


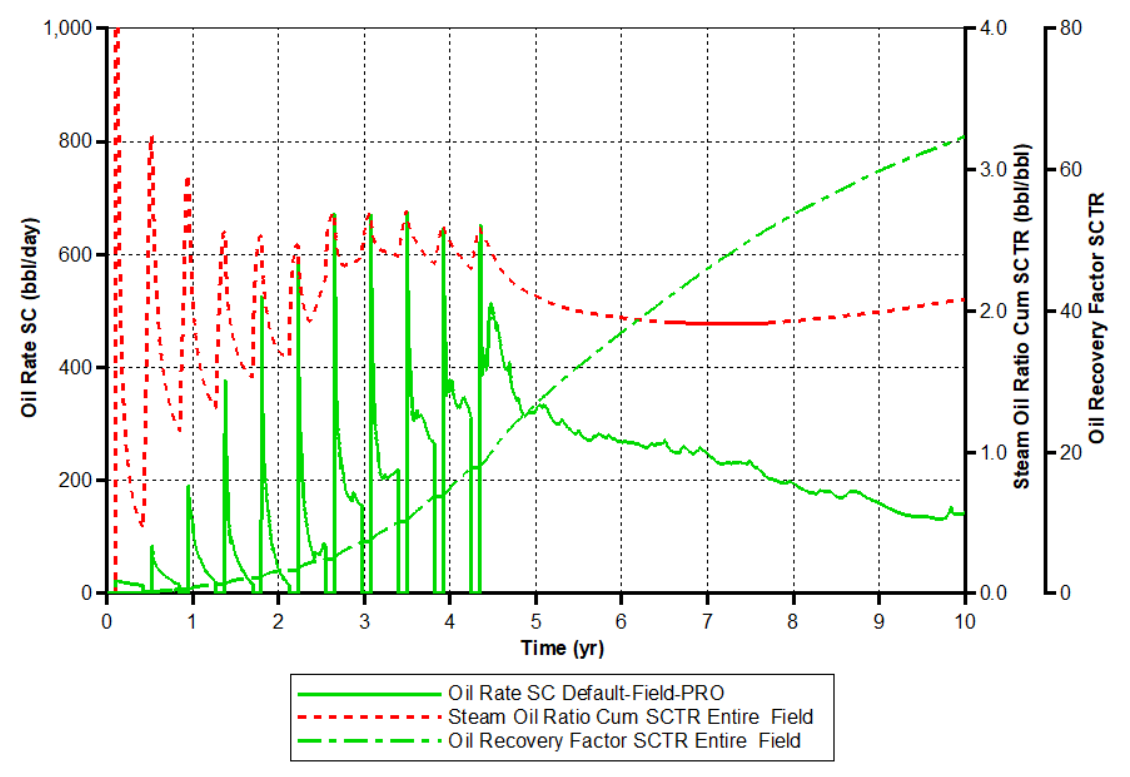

Figure 6. Production rate in the combination of CSS and steam flooding

Figure 7 presents the heat distribution of combining CSS and steam flooding. There is a continuous steam injection in the center part of the reservoir, while the CSS wells are in the edge parts. As shown in Figure 7 , the steam soar from the center and both sides of the reservoir. This phenomenon indicates that the steam chamber volume more spreads. Hereafter, the reservoir area is heated wider. In this case, the recovery factor is higher, and cSOR is even lower.

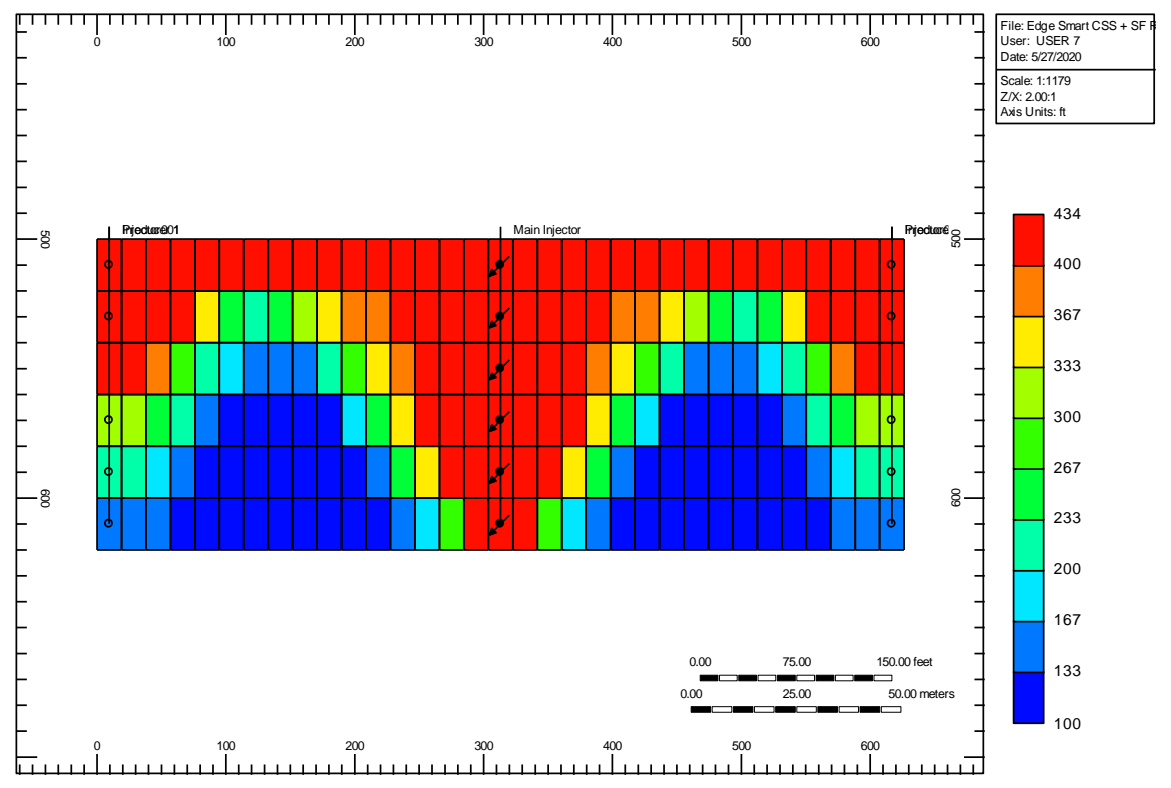

Figure 7. Temperature distribution of scenario 3 at the $4^{\text {th }}$ year simulation

\section{CONCLUSION}

The simulation result indicates that the combination of the CSS and the steam flooding can be more profitable compared to the CSS and the steam flooding individually. This combination makes the steam grow up more spread so that the steam can heat more reservoir volume. As a result, the cumulative oil production increases, the cSOR decreases, and the heat efficiency are going up. Here, the steam injection will be more favorable. Based on the simulation result, this combination yielded a recovery factor of approximately $63 \%$ and the cSOR of about 2.1 . 


\section{Acknowledgements}

This work was supported by Lembaga Penelitian dan Pengabdian Kepada Masyarakat, Universitas Pembangunan Nasional Veteran Yogyakarta (Grant No: B/286/UN.62/PT/X/2019).

\section{References}

Ali, S. M. F. (1994). CSS - Canada's Super Strategy For Oil Sands. Journal of Canadian Petroleum Technology, 33(09). https://doi.org/10.2118/94-09-01

Azad, M. S., Alnuaim, S., \& Awotunde, A. A. (2013). Stochastic optimization of cyclic steam stimulation in heavy oil reservoirs. Society of Petroleum Engineers - Kuwait Oil and Gas Show and Conference, KOGS 2013, 896-912. https://doi.org/10.2118/167378-ms

Butler, R. M. (1991). Thermal Recovery of Oil and Bitumen. Prentice Hall.

Gael, B. T., Gross, S. J., \& McNaboe, G. J. (1995). Development planning and reservoir management in the Duri steam flood. SPE Annual Western Regional Meeting, 533-546. https://doi.org/10.2118/29668-ms

Hong, K. C. (1994). Steamflood Reservoir Management: Thermal Enhanced Oil Recovery. PennWell Books.

Hong, K. C., \& Stevens, C. E. (1990). Water-alternating-steam process improves project economics at west coalinga field. Annual Technical Meeting, ATM 1990, 841-8415. https://doi.org/10.2118/9084

Hou, J., Zhou, K., Zhao, H., Kang, X., Wang, S., \& Zhang, X. (2016). Hybrid optimization technique for cyclic steam stimulation by horizontal wells in heavy oil reservoir. Computers and Chemical Engineering, 84, 363-370. https://doi.org/10.1016/j.compchemeng.2015.09.016

Kusumastuti, I., Erfando, T., \& Hidayat, F. (2019). Effects of Various Steam Flooding Injection Patterns and Steam Quality to Recovery Factor. Journal of Earth Energy Engineering, 8(1), 33-39. https://doi.org/10.25299/jeee.2019.vol8(1).2909

Melysa, R. (2016). Prediksi Kinerja Steamflood Dengan Metode Myhill-Stegemeier dan Gomaa di Area R Duri Steamflood (DSF). Journal of Earth Energy Engineering, 5(2), 44-56. https://doi.org/10.22549/jeee.v5i2.478

Nasr, T. N., \& Ayodele, O. R. (2005). Thermal techniques for the recovery of heavy oil and bitumen. SPE International Improved Oil Recovery Conference in Asia Pacific, 87-101. https://doi.org/10.2118/97488-ms

Sheng, J. J. (2013). Cyclic Steam Stimulation. In Enhanced Oil Recovery Field Case Studies (1st ed., pp. 389-412). Elsevier Inc. https://doi.org/10.1016/B978-0-12-386545-8.00016-6

Suranto, A. M., Permadi, A. K., \& Bae, W. (2016). Smart completion design in cyclic steam stimulation process: An alternative for accelerating heavy oil recovery. International Journal of Oil, Gas and Coal Technology, 11(2), 127-140. https://doi.org/10.1504/IJOGCT.2016.074289

Suranto, Bae, W., Permadi, A. K., Park, Y., Lasahido, M. R., Migas, S. K. K., Dang, S. T., \& Naser, M. A. (2014). A comprehensive investigation of WASP application in heavy oil using response surface methodology. SPE International Heavy Oil Conference and Exhibition 2014: Heavy Oil Innovations Beyond Limitations, 290-298. https://doi.org/10.2118/172878-ms 